\title{
EFFECT OF STOCKING DENSITY ON GROWTH PERFORMANCE AND PRODUCTION OF SILVER CARP (Hypohthalmichthys molitrix) CULTURED IN FLOATING CAGES.
}

Mostafa, M. A. A. ; I. M. A. Samra and M. E. I. Radwan

Dept. Aquaculture, Central Laboratory for Aquaculture Res., Abbassa, Abo-Hammad, Sharkia Governorate, Egypt.

\begin{abstract}
Silver carp $(H$. molitrix) fingerlings with initial weight of $20.1 \mathrm{~g}$. were stocked at a rate of 2500,5000 and 10000 fish/cage in 6 cages (two cages per treatment) each of $9 \times 6 \times 3 \mathrm{~m}$. The total duration of experiment was 10 months (300 day).

Wight gain and specific growth rate were significantly decreased with increasing stocking density.

The highest net return was obtained with stocking density of $5000 \mathrm{fish} /$ cage, while the lowest net return was obtained with stocking density of 2500 fish/cage. Survival was negatively correlated with stocking densities through the experimental period.

In conclusion, the optimum stocking density of Silver carp under the conditions of this experiment is 5000 fish/cage in terms of growth performance, total production and net return.

Keywords : Silver carp, Stocking density, Cages, Growth performance, Economic efficiency.
\end{abstract}

\section{INTRODUCTION}

Cage aquaculture is one of the main freshwater intensive culture patterns in Egypt, due to its benefits in terms of increased fish production and its feasible profit. During the fish cage culture, a large amount of waste materials was brought into the water directly (Longgen and Zhongjie, 2003).

Site selection is a key factor in any aquaculture operation, affecting both success and sustainability of the culture activity. The correct choice of the site in any aquatic farming operation is vitally important since it can greatly influence economic viability by determining capital outlay, and by affecting running costs, rates of productions and mortality factors. It is impractical to try control water quality parameters in cage culture systems, therefore culture of any species must be established in geographical regions having adequate water quality and exchange(P'erez et al., 2003).

Stocking density is one of the most important variables in aquaculture because it directly influences survival, growth, behavior, health, water quality, feeding and production. In cage culture, optimum stocking density and carrying capacities vary with species, size of fish, size of cages, rate of water exchange, size of ponds and length of growing season (Kilambi et al., 1977; Chua and Teng, 1979; Coche, 1982; McGinty,1991; Beveridge, 2002; Chua and Tech, 2002; and Masser,2004). Production strategies often involve the manipulation of densities by harvesting, grading and transferring fish to 
larger-mesh cages during the culture period (Campbell,1985; Schwedler et al., 1989; Bbeveridge, 1996\& 2002; Lazur,1996; Ahmad et al.,1999;and Liao et al., 2004).Consequently, optimum stocking densities need to be determined for each species and production phase to enable efficient management and to maximize production and profitability.

The aim of this work was to evaluate the effect of stocking density on growth performance, total fish production and to determine the impacts of this cages and stocking density on water quality and economical efficiency of silver carp $(H$. molitrix) reared in cages.

\section{MATERIALS AND METHODS}

The present study was carried out in branch of the River Nile (Rasheed branch) at Behira governorate, Egypt.

The water at the experimental study hard an average salinity ranging between 1-2 $\mathrm{g} / \mathrm{L}$. the experiment started at $1^{\mathrm{st}}$ March 2008 and lasted at the $1^{\text {st }}$ of January 2009 (10 months).

Three cage units each contained 2 cages each of them $9 \times 6 \times 3 \mathrm{~m}$. The water depth of the cage site was $6 \mathrm{~m}$, whereas the floating part of the cage depth was $25 \mathrm{~cm}$. The cage net was double layers. The first group of 2 cages represented stocking density 2500 fish fingerlings for one cage averaging $20.1 \mathrm{~g}$ in weight ( in duplicate). The second group represented stocking density 5000 fish fingerlings(for one cage, the same average weight cited above, in duplicate).

The third group represented stocking density 10000 fish fingerlings (for one cage, the same average weight cited above, in duplicates). The fish were purchased from Saft khaled Hatchery, Behera governorate, belonging to the General Authority for fish Resources, Ministry of Agriculture.

Live body weight and body length of random sample of 150 fish from each cage were taken at start and every 15 days and were recorded till the termination of the experiment. The fish were netted from the water and weighted to the nearest gram. Standard weight and length of fish was measured at the beginning and at the end of the experimental period to nearest $\mathrm{g}$ and $\mathrm{mm}$, respectively. Then the fish were returned immediately to their cages. Water temperature, dissolved oxygen and $\mathrm{pH}$ were measured daily at 6 a.m. and 12 p.m. using temperature and dissolved oxygen meter (YSI 57) and pH meter (model corning 345).

Transparency and Turbidity were measured every two weeks by Sicchi disk and (Hack) spectrophotometer (model 41700) using Hack Kits. Determinations of water quality parameters (salinity, ammonia and phosphorus) were carried out every month according to the methods of Boyd (1979). Phytoplankton and zooplankton communities in cage water were determined every month according to the methods described by Boyd (1990) and A.P.H.A. (1985). Samples were calculated from different sites of the experimental cages randomly to represent the water of the whole cages.

Parameters of specific growth rate (SGR, \%/d) and daily weight gain were calculated according to the following equations: 
SGR, \%/d = $100\left(\mathrm{LnW}_{2}-\mathrm{LnW}_{1}\right) / \mathrm{T}_{2}-\mathrm{T}_{1}$ (Bagenal and Tesch, 1978) Where: $W_{1}$ and $W_{2}$ are the first and following fish weight in grams, Ln is the natural logarithm and $T$ is the growing period in days .

Where: W1 was the initial weight

$$
\text { Daily weight gain }=(\mathrm{W} 2-\mathrm{W} 1) / \mathrm{T}
$$

W2 was final weight

$T$ is the growing period

After ten months of fish culture, silver carp was harvested from each cages .

\section{Statistical analysis :}

The statistical analysis of data was performed using the analysis of variance(ANOVA). Duncan's multiple range test (Duncan, 1955) was used to determine the significant differences between means at $\mathrm{P}<0.05$. Standard errors of treatment means were also estimated. All statistical evaluations were carried out using statistical analysis systems program (SAS, 2002).

\section{RESULTS AND DISCUSSION}

\section{Water quality parameters :}

Averages water quality parameters as affected by different stocking densities are presented in Table (1). Results revealed that transparency (Sicchi disk reading, $\mathrm{cm}$ ) had ranged between $15 \mathrm{~cm}$ and $16 \mathrm{~cm}$. These values are beneficial to fish culture. In this connection, Mahmoud (1997) and Abdel-Hakim et al. (2000) reported that stocking densities had influence on Sicchi disk reading.

Table (1): Averages of water quality parameters of cages during the experiment ( 10 months)

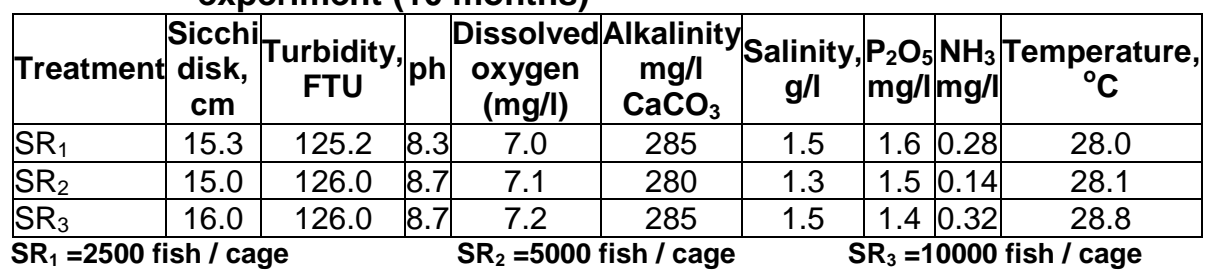

Turbidity is one of the physical properties that are greatly affected by culture of silver carp (Hypophthalmichthys molitrix). It has been determined as FTU and had ranged between 125.2 and 126.0 which show a similar trend for all treatments, the same direction was observed in water temperature when the average was found to be between $28.0 \mathrm{C}^{\circ}$ and $28.8 \mathrm{C}^{\circ}$ (Table 1).

The different values of water temperature in cages in all treatments may be attributing to the increase of number of fish that may lead to temperature increases. These are in agreement with results of Mahmoud (1997) and Shaker and Mahmoud (2007) who reported a slight increase in water temperature with increasing the stocking density. Transparency, 
Mostafa, M. A. A. et al.

turbidity and temperature values are in the range recommended for this fish species cultured in the three treatments.

Average of dissolved oxygen (DO) had ranged between 7.0 to $7.2 \mathrm{mg} / \mathrm{l}$. These values are beneficial to fish culture and indicate that water dissolved oxygen slight decreased in heavy cages compared to the other cages. This may be attributed to the increase in organic matter contents of the heavy cages, which may lead to DO decreases.

Averages of phosphorus had ranged between 1.4 to $1.6 \mathrm{mg} / \mathrm{l}$. which represent the normal range of phosphorus in fish cages. In this connection, Forts et al (1986) and Salama (2003) showed that the available phosphorus was significantly $(P<0.01)$ highest at low density. They added that there were indications that phosphorus content increased in the soil, although total phosphorus in the soil contributed by about $0.8 \%$ of the water phosphorus.

\section{Plankton communities : \\ Phytoplankton :}

Results present in Table (2) illustrate the effect of treatments on phytoplankton communities. The total phytoplankton for treatments $\mathrm{SR}_{1}, \mathrm{SR}_{2}$ and $\mathrm{SR}_{3}$ were 4937,3988 and 3261 organisms/l. respectively on the average. Results presented in this Table indicated that the phytoplankton total counts increased in the cages stocked at lower density. The results of Table (2) indicated that the highest phytoplankton values were obtained by the $S_{1}$ treatment followed in a decreasing order by $\mathrm{SR}_{2}$ and $\mathrm{SR}_{3}$ treatment, respectively. These results could be explained by the fact that low number of fish has more natural food compared with other treatments.

Table(2):Least square means and standard errors for abundance in all experimental groups .

Phytoplankton (organisms/l)

\begin{tabular}{|l|c|c|c|c|c|}
\hline Treatments & $\underset{* \star \star}{\text { Chlorophyta }}$ & Cyanophyta & Bacillarophyta & $\begin{array}{c}\text { Total } \\
\text { phyto } \\
\text { phytankton } \\
\star \star \star *\end{array}$ & $\begin{array}{c}\% \text { of the } \\
\text { smallest } \\
\text { value }\end{array}$ \\
\hline $\mathrm{SR}_{1}$ & $2233 \pm 18.3$ & $1473 \pm 13.2$ & $1231 \pm 28.2$ & $4937 \pm 103.5$ & $151.39 \%$ \\
\hline $\mathrm{SR}_{2}$ & $1915 \pm 18.3$ & $1113 \pm 13.2$ & $960 \pm 28.2$ & $3988 \pm 103.5$ & $122.29 \%$ \\
\hline $\mathrm{SR}_{3}$ & $1620 \pm 18.3$ & $1011 \pm 13.2$ & $630 \pm 28.2$ & $3261 \pm 103.5$ & $100 \%$ \\
\hline
\end{tabular}

Zooplankton (organisms/l)

\begin{tabular}{|l|c|c|c|c|c|}
\hline Treatments & $\begin{array}{c}\text { Rotifer } \\
\star \star\end{array}$ & $\begin{array}{c}\text { Copepoda } \\
\star \star\end{array}$ & $\begin{array}{c}\text { Cladocera } \\
\star \star\end{array}$ & $\begin{array}{c}\text { Total } \\
\text { zooplankton } \\
\star \star \star\end{array}$ & $\begin{array}{c}\% \text { of the } \\
\text { smallest value }\end{array}$ \\
\hline $\mathrm{SR}_{1}$ & $1542 \pm 23.5$ & $789 \pm 24.3$ & $788 \pm 13.3$ & $3119 \pm 162$ & $161.27 \%$ \\
\hline $\mathrm{SR}_{2}$ & $1280 \pm 23.5$ & $613 \pm 24.3$ & $530 \pm 13.3$ & $2428 \pm 162$ & $125.54 \%$ \\
\hline $\mathrm{SR}_{3}$ & $1013 \pm 23.5$ & $511 \pm 24.3$ & $410 \pm 13.3$ & $1934 \pm 162$ & $100 \%$ \\
\hline
\end{tabular}

\begin{tabular}{l|r|r}
$\mathrm{SR}_{3}$ & $1013 \pm 23.5$ & $511 \pm$ \\
${ }^{* *} \mathrm{p}<0.01$ & ${ }^{* \star *} \mathrm{p}<0.001$
\end{tabular}

The results of present study indicates that Chlorophyta is the dominated group followed by Cyanophyta and Bacillarophyta in all treatment cages (Table 2). This community composition of phytoplankton reported in this study is in confirmation with observations of El-Serafy and Al-Zahaby (1991) and Abdel-Hakim et al (2000) who pointed out that Chlorophyta 
predominated all the other groups followed by Cyamophyta and Bacillarophyta.

Zooplankton :

Results presented in Table (2) illustrate the effect of treatments on zooplznkton counts for treatments $\mathrm{SR}_{1}, \mathrm{SR}_{2}$ and $\mathrm{SR}_{3}$ which were 3119,2428 and 1934 organisms/l, respectively on the average. Results presented in this Table indicated that the lowest total zooplznkton counts were obtained by the treatment $\mathrm{SR}_{3}$ followed in an increasing order by $\mathrm{SR}_{2}$ and $\mathrm{SR}_{1}$ treatments, respectively. The present study indicates that Rotifer is the dominat group followed by Copepoda and Cladocera in all the treatment cages. This community composition of zooplankton is not in conformity with those observed of El-Serafy and Al-Zahaby (1991) who pointed out that Copepoda was predominated all the order groups. These results may be due to differences in the nature of the environmental conditions and feeding habits of the different fish species.

These results indicate that the community composition of phytoplankton and zooplankton in all treatments fluctuated greatly with temperature. Fertilization and feeding habits of fish in this concern, Riely (1947) reported that statically the relation of total zooplankton and total phytoplankton had no strict relationship (not significant).

Based on the obtained results it could be recommended the use of intensevecation in cages culture of silver carp.

Growth performance:

Averages of body weight of Silver carp as affected with stocking density during the experimental periods are presented in Table (3). At the start of the experiment averages of initial weight ranged between 20.11 and $20.7 \mathrm{~g}$ and differences between the experimental groups were insignificant indicating that distribution of experimental fish were completely random. Ten monthes after the experimental start, results revealed that averages of body weight of silver carp increased significantly $(P<0.05)$ at the lower stocking density. At the end of experimental period, averages of final weights were $891.14,788.13$ and $720.15 \mathrm{~g}$ for the groups $\mathrm{SR}_{1}, \mathrm{SR}_{2}$ and $\mathrm{SR}_{3}$, respectively .

Table (3): Means and standard error for the effect of treatments on the body weight(BW)of silver carp (H..molitrix)

\begin{tabular}{|c|c|c|c|c|c|c|}
\hline Variable & $\begin{array}{c}\text { Start } \\
\left(B E W_{1}\right)\end{array}$ & $\begin{array}{c}2 \\
\text { months } \\
\left(\mathrm{BW}_{2}\right)\end{array}$ & $\begin{array}{c}4 \\
\text { months } \\
\left(\mathrm{BW}_{4}\right)\end{array}$ & $\begin{array}{c}6 \\
\text { months } \\
\left(B W_{6}\right)\end{array}$ & $\begin{array}{c}8 \\
\text { months } \\
\left(B W_{8}\right)\end{array}$ & $\begin{array}{c}10 \\
\text { months } \\
\left(B W_{10}\right)\end{array}$ \\
\hline $\mathrm{SR}_{1}=2500 \mathrm{Fish} / \mathrm{cage}$ & $\begin{array}{l}20.8 \pm \\
0.66^{\mathrm{a}}\end{array}$ & $\begin{array}{c}180.13 \pm \\
1.13^{\mathrm{a}} \\
\end{array}$ & $\begin{array}{c}290.12 \pm \\
167^{\mathrm{a}} \\
\end{array}$ & $\begin{array}{c}489.13 \pm \\
1.78^{\mathrm{a}} \\
\end{array}$ & $\begin{array}{c}781.12 \pm \\
1.31^{\mathrm{a}} \\
\end{array}$ & $\begin{array}{c}891.14 \pm \\
2.18^{\mathrm{a}} \\
\end{array}$ \\
\hline $\mathrm{SR}_{2}=5000$ Fish / cage & $\begin{array}{c}20.11 \pm \\
0.47^{\mathrm{a}}\end{array}$ & $\begin{array}{c}162.15 \pm \\
1.18^{\mathrm{b}} \\
\end{array}$ & $\begin{array}{c}270.15 \pm \\
1.13^{\mathrm{b}}\end{array}$ & $\begin{array}{c}418.33 \pm \\
1.40^{\mathrm{b}}\end{array}$ & $\begin{array}{c}678.14 \pm \\
2.68^{\mathrm{b}} \\
\end{array}$ & $\begin{array}{c}788.13 \pm \\
3.16^{\mathrm{b}}\end{array}$ \\
\hline $\mathrm{SR}_{3}=10000 \mathrm{Fish} /$ cage & $\begin{array}{l}20.7 \pm \\
0.57^{\mathrm{a}}\end{array}$ & $\begin{array}{c}148.51 \pm \\
1.53^{\mathrm{c}}\end{array}$ & $\begin{array}{c}261.18 \pm \\
1.34^{\mathrm{c}}\end{array}$ & $\begin{array}{c}380.12 \pm \\
1.08^{\mathrm{c}}\end{array}$ & $\begin{array}{c}590.43 \pm \\
2.17^{\mathrm{c}}\end{array}$ & $\begin{array}{c}720.15 \pm \\
3.10^{c}\end{array}$ \\
\hline
\end{tabular}

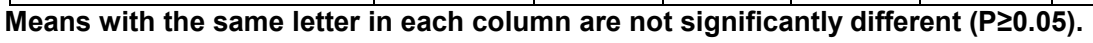

The analysis of variance for final body weight indicates that final body weights of silver carp increased significantly $(P<0.05)$ with lower stocking density. 
Mostafa, M. A. A. et al.

Table (4) also shows that the body length of Silver carp increased from 12.3 to $37.5,12.8$ to 35.7 and 12.26 to $35.1 \mathrm{~cm}$. for $\mathrm{SR}_{1}, \mathrm{SR}_{2}$ and $\mathrm{SR}_{3}$, respectively.

Table (4): Means and standard error for the effect of treatments on the body length (BL)of silver carp (H..molitrix)

\begin{tabular}{|l|c|c|c|c|c|c|}
\hline Variable & $\begin{array}{c}\text { Start } \\
\left(\mathrm{BL}_{1)}\right)\end{array}$ & $\begin{array}{c}\text { months } \\
\left(\mathrm{BL}_{2}\right)\end{array}$ & $\begin{array}{c}\text { months } \\
\left(\mathrm{BL}_{4}\right)\end{array}$ & $\begin{array}{c}\mathbf{6} \text { months } \\
\left(\mathrm{BL}_{6}\right)\end{array}$ & $\begin{array}{c}\mathbf{8} \text { months } \\
\left(\mathrm{BL}_{8}\right)\end{array}$ & $\begin{array}{c}\mathbf{1 0} \text { months } \\
\left(\mathrm{BL}_{10}\right)\end{array}$ \\
\hline $\mathrm{SR}_{1}=2500 \mathrm{Fish} /$ cage & $12.3 \pm$ & $20.11 \pm$ & $28.31 \pm$ & $33.13 \pm$ & $35.2 \pm$ & $37.5 \pm$ \\
& $0.13^{\mathrm{a}}$ & $0.15^{\mathrm{a}}$ & $0.16^{\mathrm{a}}$ & $0.18^{\mathrm{a}}$ & $0.15^{\mathrm{a}}$ & $0.18^{\mathrm{a}}$ \\
\hline $\mathrm{SR}_{2}=5000 \mathrm{Fish} /$ cage & $12.8 \pm$ & $19.81 \pm$ & $26.80 \pm$ & $33.00 \pm$ & $34.15 \pm$ & $35.7 \pm$ \\
& $0.18^{\mathrm{a}}$ & $0.13^{\mathrm{b}}$ & $0.11^{\mathrm{b}}$ & $0.15^{\mathrm{a}}$ & $0.13^{\mathrm{b}}$ & $0.16^{\mathrm{b}}$ \\
\hline $\mathrm{SR}_{3}=10000$ Fish/ cage & $12.26 \pm$ & $19.18 \pm$ & $26.40 \pm$ & $31.38 \pm$ & $33.2 \pm$ & $35.1 \pm$ \\
& $0.9^{\mathrm{a}}$ & $0.18^{\mathrm{c}}$ & $0.15^{\mathrm{b}}$ & $0.13^{\mathrm{b}}$ & $0.19 \mathrm{C}$ & $0.13^{\mathrm{b}}$ \\
\hline
\end{tabular}

Means with the same letter in each column are not significantly different $(P \geq 0.05)$

The results indicated that stocking density of cages with silver carp fingerlings at a density of $(2500 \mathrm{fish} / \mathrm{cage})$ resulted in higher $(P<0.05)$ final weight compared to higher stocking density (10000 fish/cages). These results are in agreement with results of Hafiz and Abdel-Hakim (1998) who reported that final weights increased with decreasing stocking density of silver carp cultured in earthen ponds and the increases was more propounded when the fish were stocked at lower density (3200 fish/feddan) compared to those stocked at higher density (4800 fish/feddan).

As described in Table (5) the average body weight of silver carp increased from about $20.5 \mathrm{~g}$ to $891.14,788.13$ and $720.15 \mathrm{~g}$ for $\mathrm{SR}_{1}, \mathrm{SR}_{2}$ and $\mathrm{SR}_{3}$, respectively.

Table(5): Growth performance of silver carp in cages.

\begin{tabular}{|l|c|c|c|}
\hline \multicolumn{1}{|c|}{ Treatments } & SR1 & SR2 & SR3 \\
\hline Initial Body weight(g) & $20.8 \pm 0.18 \mathrm{a}$ & $20.11 \pm 0.18 \mathrm{a}$ & $20.70 \pm 0.18 \mathrm{a}$ \\
\hline Final body weight $(\mathrm{g})$ & $891.14 \pm 2.18 \mathrm{a}$ & $788.13 \pm 3.16 \mathrm{~b}$ & $720.15 \pm 3.10 \mathrm{c}$ \\
\hline Weight gain (g) & 870.34 & 768.02 & 599.45 \\
\hline Daily gain (g) & 3.62 & 3.20 & 2.49 \\
\hline Specific growth rate (S.G.R \%/d) & 2.82 & 2.77 & 2.67 \\
\hline
\end{tabular}

Means with the same letter in each column are not significantly different $(P \geq 0.05)$.

Daily gain (g) was between 2.49 and $3.62 \mathrm{~g}$. Specific growth rate (SGR) recorded 2.82, 2.77 and $2.67 \% / d$ for $\mathrm{SR}_{1}, \mathrm{SR}_{2}$ and $\mathrm{SR}_{3}$, respectively. These values are in agreement with those reported by Bakeer (2001), who found that SGR of silver carp was very closed with the present results.

Table (6) shows that fish yields in the present study were 2116.00; 3743.61 and $5041.05 \mathrm{~kg} / \mathrm{cage}$ for $\mathrm{SR}_{1}, \mathrm{SR}_{2}$ and $\mathrm{SR}_{3}$, respectively. As illustrated, the fish yield in the present study was higher than that obtained by Hafez et al. (1998) and Bakeer (2001), who found that total fish yields of silver carp were 1277.95 and $2482.44 \mathrm{~kg} / \mathrm{cage}$ when the their stocking rate was 2500 and 5000 fish/cage under the same conditions and the size of cages. 


\section{Survival Rate:}

As shown in table (6) survival rate were $95.0 \%, 95.0 \%$ and $70.0 \%$ for $\mathrm{SR}_{1}, \mathrm{SR}_{2}$ and $\mathrm{SR}_{3}$, respectively. These results are in agreement with Bakeer (2001) who obtained the same survival rate for silver carp in cage culture.

\section{Economic Efficiency:}

Table (6) shows the result of economical evaluation including the costs and results for treatments applied in $\mathrm{kg} /$ cage and income in (L.E) for 10 month. Total costs were 9000,10000 and 12000 L.E/ cage for $\mathrm{SR}_{1}, \mathrm{SR}_{2}$ and $\mathrm{SR}_{3}$, respectively. These results revealed that the total cost of $\mathrm{SR}_{3}$ was the highest than the other groups. On the other hand, the total cost of $\mathrm{SR}_{1}$ was the lowest due to the stocking rate. Net returns in L.E per cage were 1580, 8718.05 and 8184.2 for $\mathrm{SR}_{1}, \mathrm{SR}_{2}$ and $\mathrm{SR}_{3}$, respectively. Percentage of net return to total cost for treatments were $17.55,87.18$ and $68.03 \%$ for $S_{1}$, $\mathrm{SR}_{2}$ and $\mathrm{SR}_{3}$, respectively indicating that the highest net returns were obtained with the group $\mathrm{SR}_{2}$ followed by $\mathrm{SR}_{3}$ and $\mathrm{SR}_{1}$. These results indicate that stocking of silver carp at density of 5000 fish/cage is most profitable procedure for fish cage culture.

Table (6): Economic efficiency (\%) of silver carp in cage culture (L.E/ cage).

Stocking rate(fish/cage):

Average size at stocking $(\mathrm{g})$

Average size at harvesting $(\mathrm{g})$

Survival rate( \%)

Production( kg/cage)

Operating costs:

\begin{tabular}{|l|r|}
\hline Fish fingerlings & 1000 \\
\hline
\end{tabular}

Labor Cone (cage)

Others

Total costs cage

$\%$ of the smallest value of total cost

Returns:

\begin{tabular}{|l|c|c|c|}
\hline Total returns & 10580 & 18718.05 & 20164.2 \\
\hline Net returns & 1580 & 8718.05 & 8184.2 \\
\hline$\%$ net return to total cost & $17.55 \%$ & $87.18 \%$ & $68.03 \%$ \\
\hline
\end{tabular}

$\%$ net return to total cost

\section{(\%) of silver carp in cage culture}

in 2008 in L.E.

SR1 Price for one $\mathrm{Kg}=5$ L.E.

SR2 Price for one $\mathrm{Kg}=5 \mathrm{~L} . \mathrm{E}$.

SR3 Price for one $\mathrm{Kg}=4 \mathrm{~L} . \mathrm{E}$.

\section{Recommendation:}

Based on the obtained results, cage stocking with 5000 fish weighting $20 \mathrm{~g}$ could be recommended for growing silver carp (H. molitrix) 


\section{Acknowledgment}

Appreciation extended to Prof. Dr. M. Bakeer Deputy Director of CLAR at Abbassa Center and Mr. Mamdouh Nossiear head of Aquaculture Department, Behira Rural Development Project, for providing helps and assistance during the study.

\section{REFERENCES}

Abdel-Hakim, N.F., Bakeer, M.N.and Soltan. MA. (2000). Effect of two manuring systems on water quality and plankton communities in fishponds. Conference of Social and Agriculture Development of Sinai (D43-59), pp: 147-158, EL- Arish Faculty of Env. Agr. Sci.

Ahmad, T A.; EL-Zahr, C. and Wuan, T.O. (1999). Nursing and production of the grouper Epinephelus coioides at different stocking densities in tanks and sea cages. Asian Fish. Sci., 12:267-276

American Public Health Association (A.P.H. A.) (1985). Standard method for the examination of water and waste water. Ed. American Public Health Association . Washington, pp. 1268.

Bagenal, T. B and Tesch. F.W (1978). Age and growth In Bagenal, T. (Ed.) Methods for Assessment of fish production in Fresh Waters. IBP Handbook 3. Blackwell, Oxford, U.K..KM-136.

Bakeer, M. N. (2001). Growth responses of silver carp (Hypophthalmichthys molimx) cuhmed in cages to manuring at different stocking densities. Annals of Agric. Sci. Moshtohor., 19 (3): 1517- 1529. (2001).

Beveridge, M.C.M. (1996). Cage Aquaculture. Fishing News Books,Carlton. 346.

Beveridge, M.C.M., (2002). Overview of cage culture. In:Woo,P.T.K., Bruno, D.w., Lim, L.H.S. (Eds.), Diseases and Disorders of finfish in cage culture. CABI Publishing, Oxon, 41-59.

Boyd. C. E. (1979): Water quality in warm water fish ponds. Ed. Claude E. Boyd. Third edition. 1984 Pub. Auburn Univ.. Agri. Exp. Station. AID/Dsan-CG.0039.pp 359. Boyd. C E, (1983): Water quality management for pond fish culture. Elsevier Scientific Publishing Company. New York. 3l8pp

Boyd. C E.. (1990): Water quality in ponds foi aquaculturc. Alabama agric.Experiment station. Auburn Univ., Alabama. Calabrese. A. (1969): Effects of acids and alkalies on survival of blucgills and iargeniouth bass. U.S. fish wild Ser. Tech Paper 42.

Campbell, $\mathrm{D}(1985)$. Large scale cage farming of Saotherodon niloticus. Aquacult., 48:57-69.

Chua, T. E. and Tech, E.(2002). Introduction and historyof cage culture. In: Woo, P.T.K., Bruno, D.w., Lim, L.H.S. (Eds.), Diseases and 306. J. Roland et al./ Aquacult. 253(2006) 301-308 Disorders of finfish in cage culture. CABI Publishing, Oxon, pp. 1-39.

Chua, T. E. and Teng, S. K. (1979). Relative growth and productionof the estuary grouper Epinephelus salmoides under different stocking densities in floating net-cages. Mar. Biol., 54: 363-372. 
Coche, A. G. (1982). Cage culture of tilapias. In: pullin, R S. V., loweMcConnell, R.H. (Eds.), the Biologyand culture of tilapias.ICLARM, Manila, Philippines, 205-246.

Duncan, D B. (1955): Multiple range and multiple F test. Biometrics. 11:1-42.

El- Serafy. S. S. and AL-Zahaby. S A. (1991): Plankton in the tradition and improved technique of fish culture. Egypt. J. Appl. Sci., 6(10): 1991:429-440

Fortes. R. D.. Corre. V.L. and Pudadera. E (1986): Effect of fertilizers and i'eedsas Nutrient sources on Oreochrmtiis miniums production in Philippinebrackish water ponds. In J.L. MacLean, L. B. Dion and J. V. Hostiies. The first Asian fisheries forum. Asian fisheries society. Manila. Philippine, 121-124.

Hafez. A.F. and Abdel- Hakim. N.F..(1998) Performance of Silver carp as affect by level of duck manuring and slocking density. Egypt J. Agric. Res., 76 (3). 1297-1305.

Kilambi, R. V., Adams, J. C. Brown, A. V. and Wickizer, W. A. (1977). Effect of stocking density and cage size on growth, feed conversion and production of rainbow trout and channel catfish.Prog.Fish-Cult., 39:6266.

Lazur, A. M. (1996). The effect of periodic grading on production of channel catfish cultured in cages. J. Appl. Aquac., 6:17-24.

Liao, I. C.; Tsia, W. S.; Hseuh, C. M.; Chang, S. L. and Lean, E. M. (2004).Cobia culturein Taiwan: current status and problems. Aquacult., 237:155-165.

Longgen, G. and Zhongjie, L. (2003).Effect of nitrogen and phosphorus from fish cage-culture on the communities of a shallow lake in middle Yangtze River basin of China Aquacult., 226: 201-212.

Mahmoud. A. A. (1997). Effect of duck manure as organic fertilizer on productivity of silver carp under Egyptian conditions M Sc. Thesis. Faculty of Agriculture. AL-Azhar University.

Masser, M. P(2004). Cages and in-pond raceways. In: Tucker, C.S; Hargreaves, J.A. (Eds.)Biology and culture channel catfish. Elsevier, Sydney, 530-544.

McGinty, A. S. (1991). Tilapia production in cages: effects of cage size and number of non-caged fish. Prog. Fish-Cult., 53:246-249.

Pe'res, O. M.;Ross, L. G.; Telfer, T. C. and Barquin, L. M. C. (2003). Water quality requirements for marine fish cage site selectin in Tenerife (Canary Islands):Predictive modeling and analysis using GIS. Aquacult., 224: 51-68.

Riely, G. A. (1947). Seasonal fluctuations of the phytoplankton production in New England Coastal Waters. J. Mar. Res., (2): 114- 125

Salama, A A. (2003). Economical evaluation of Nile tilapia (Oreochromis niloticus) culture in rice fields receiving varying feeding inputs. Egypt. J Aquat. Biol. And Fish., 8. (4):61-85(2003).

Schwedler, T. E.; Tomasso, J. R. and Collier, J. A., (1989). Production characteristics and size variability of channel catfish reared in cages and open ponds. J. World Aquac. Soc., 20(3):158-161. 
Mostafa, M. A. A. et al.

Shaker, I. M. and Mahmoud, A. A., (2007). The Biological load of Silver carp cages in river nile and their effects on water quality and growth performance. J. Aqua. Biol. And Fish., 11, (2): 119-143.

Statistical Analysis System(SAS)(2002). SAS program Ver 6.12, SAS Institute incorporation Cary, NC 275/3 USA.

$$
\begin{aligned}
& \text { تأثير الكثافة التخزينية على أداء النمو وانتاج أسماك المبروك الفضسى المربـاة فى }
\end{aligned}
$$

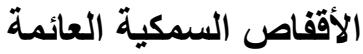

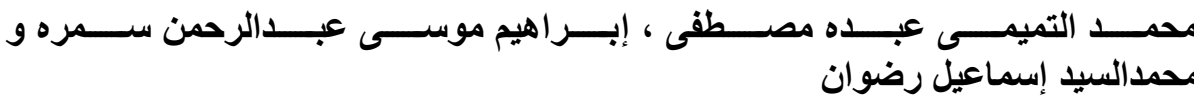

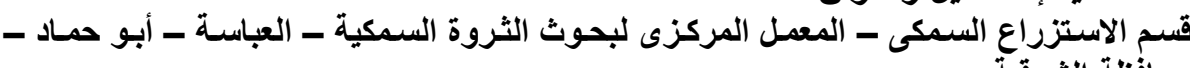

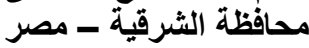

$$
\begin{aligned}
& \text { وزعت اصباعيات أسماك المبروك الفضى منوسط وزنها } 25000 \text { ، } 2000 \text { جم الى ثنلاث }
\end{aligned}
$$

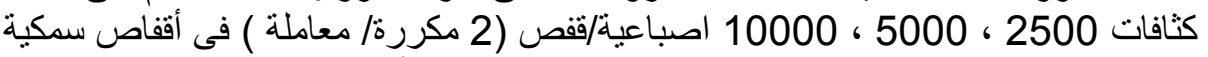

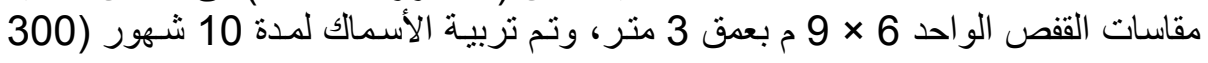

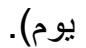

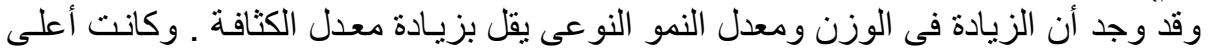

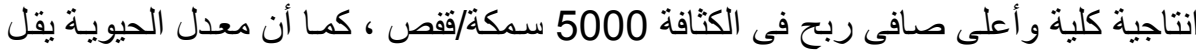

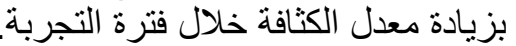

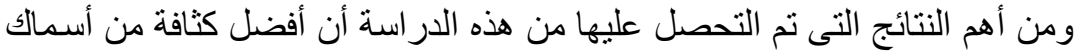

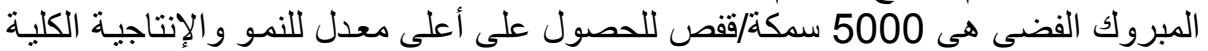

$$
\begin{aligned}
& \text { وصافى العائد. }
\end{aligned}
$$

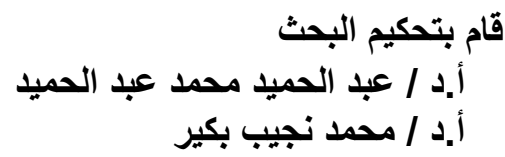

